\title{
Determinants of the Differential Pricing between Voting and Non-Voting Shares in Brazil ${ }^{1}$
}

\author{
Richard Saito*
}

\begin{abstract}
Several papers suggest that private benefits can explain the differential pricing between share classes with differential voting rights. However, in Brazil the price differential between voting and non-voting shares has been negative for several companies between July 1994 and September 2002. This paper investigates the determinants that imply this discount of voting shares vis-à-vis non-voting shares. Particularly, the paper analyzes the impacts of liquidity, dividend differential, and recent changes in legislation of the Brazilian public equity market on the voting premium. This paper ratifies that liquidity is extremely relevant to the determination of relative prices. In addition, empirical evidence confirms a negative impact of Law 9457 - revoking voting minority shareholders' tag along rights - and a positive impact of the introduction of Law 10303 - reinstating those rights to minority voting shareholders. Finally, ownership structure confirmed a positive relationship with the voting premium, but the major shareholders' voting share participation has not presented a significant relationship as in other countries.
\end{abstract}

Key Words: Voting and Non-voting Shares; Private Benefits; Liquidity, Ownership Structure, Brazil.

JEL Code: G30, G32 .

${ }^{1}$ Thanks to the participants of 2000 ANPAD Annual Meeting, 2000 SBE Annual Meeting, AB Freeman School of Business of Tulane University, FGV-EPGE, and FGV-EAESP seminars, Marco Bonomo, and William Eid Jr. for helpful comments and suggestions. I also acknowledge the research assistance from Claudio Lucinda. The usual disclaimer applies.

*Professor, Escola de Administração de Empresas de São Paulo, Fundação Getulio Vargas, Av. Nove de Julho, 2029, 01313-902 - São Paulo- SP., Tel. +55 11 3281-7899, E-mail: rsaito@fgvsp.br 
Determinants of the Differential Pricing between Voting and Non-Voting Shares

\section{Resumo}

Vários estudos sugerem que os benef ícios privados podem explicar o prêmio pelo voto de açōes com direitos superiores de voto. Entretanto, no Brasil o diferencial de preço entre ações ordinárias e preferenciais foi negativo para diversas empresas durante o período de julho 1994 até setembro 2002. Este estudo investiga os determinantes que implicam este desconto das ações ordinárias com relação às ações preferenciais. Particularmente, o estudo analisa os impactos de liquidez, diferencial de dividendos e mudanças recentes na legislaçāo brasileira do mercado de açōes sobre o prêmio pelo voto. Este estudo documenta que liquidez é extremamente importante na determinaçāo de preços relativos. Além disso, há evidência empírica confirmando o impacto negativo da Lei 9.457 revogando direitos de venda conjunta com o controlador de acionistas minoritários ordinaristas, e um impacto positivo na introduçāo da Lei 10.303 restabelecendo estes direitos para acionistas com direito a voto. Finalmente, a estrutura de posse confirmou uma relação positiva com o prêmio pelo voto, mas a participação de ações ordinárias do acionista majoritário nāo apresentou uma relação significativa como em outros países.

\section{Introduction.}

Dual class shares of a listed company with the same cash-flow rights, but with differential voting rights should in principle lead to the same price. However, a series of empirical studies confirmed that - in most secondary markets - voting shares trade at a premium ranging from $5 \%$ to $82 \%$ vis-à-vis the non-voting shares. This voting premium captures the probability of voting shareholders receiving an additional payment in the event of a control contest.

The private benefits that the controlling shareholder (or controlling blockholder) enjoys can partially explain this premium for control. Grossman and Hart (1988) and Harris and Haviv (1988) argue that private benefits determine the voting premium. Empirical evidence has been obtained in several markets. Barclay and Holderness (1989) and Lease, McConnell and Mikkelson (1983) document that superior voting shares ${ }^{2}$ are usually traded at a premium of $5 \%$ in

\footnotetext{
${ }^{2}$ For example, superior voting shares can have the equivalent to twice the number of inferior
} 
comparison with inferior voting shares. Megginson (1990) reports a premium of $13 \%$ for the UK, whereas Horner (1998) finds a premium of $20 \%$ for Switzerland, and $26 \%$ is the premium obtained in Germany by Hoffmann-Burchardi (1999). A premium of $46 \%$ is found in Israel by Levy (1983), and Zingales (1994) reports a premium of $82 \%$ for Italy.

On the other hand, there are equity markets where a discount rather than a voting premium is reported for several companies. For example, Neumann (2002) found that 13 firms out of 34 Danish listed companies had their voting shares traded at a discount in relation to non-voting shares in 1999. A similar result is obtained for the Norwegian market (Ødergaart, 1998). The Brazilian equity market also presents a discount for voting shares in several companies similar to the Nordic equity markets. Two possible reasons for this discount are (i) preference for liquidity, and (ii) differential protection of minority shareholders for each class of share (voting and non-voting).

The preference for liquidity reflects the existence of other players in the market and their wish to trade at market prices. This definition implies that liquidity is the necessary time to convert assets into cash, so that investors do not have to accept "extremely unfavorable prices". Blockholders concentrate their ownership on superior voting shares, and therefore, their participation tends to be more stable over time. Moreover, the number of superior voting shares issued is likely to be lower than the number of inferior voting shares. Therefore, superior voting shares are associated with a lower number of outstanding shares, and inferior voting shares are supposed to be more liquid.

Another aspect that has impact on the price differential between voting and non-voting shares concerns the regulation of public equity

voting shares. 
market. In Brazil, significant events that occurred in the 1997-2001 period may have influenced this price differential. The introduction of Law 9457 in May 1997 revoked tag along rights of voting shareholders, allowing the controlling group to extract private benefits from minority shareholders in the event of a takeover. However, Law 10303 of October 31, 2001 reinstated tag along rights to voting minority shareholders at $80 \%$ of that paid to the controlling shareholder (or blockholder), implying a possible increase in the voting premium (at least for minority voting shareholders).

This paper analyses the determinants of price differential between common voting shares (ON) and preferred non-voting shares (PN) of companies listed and traded on the São Paulo Stock Exchange ("BOVESPA") in the July 1994 - June 2002 period. This period presents significant changes in the institutional framework, and is marked by control transfers through privatization and control sales of Brazilian listed companies.

The paper documents that the voting premium decreases considerably from $-5.0 \%$ in 1995 to $-22.1 \%$ in 1999 , rising to $-6.7 \%$ in 2002. Empirical evidence confirms that the ON voting share price discount relative to its counterpart PN non-voting share is strongly determined by its liquidity. Second, the dividend differential paid to each class of shareholders, if that is the case, is another significant factor that affects differential pricing. Third, the study confirms that: (a) the higher the share of the voting shareholding in the company's shareholding structure, the higher the voting premium will be, and that (b) there is a positive relationship between the share of voting shares inherent to the share of voting stocks in the company's capital. The latter two empirical pieces of evidence confirm that private benefits can be reflected on the voting premium. Finally, the issue regarding public companies is analyzed for three subperiods: (a) before the enactment of Law 9457 where we had tag along 
rights for minority voting shareholders, (b) between the enforcement of Law 9457 and the enactment of Law 10303, i.e., in the absence of tag along rights, and (c) after the enactment of Law 10303. Results empirically confirm that the voting premium decreased during the period in which tag along rights were absent.

This study contributes to the existing literature in three ways. First, it reviews institutions and changes in legislation regarding the Corporate Law from July 1994 to September 2002 in Brazil and its impact on the voting premium. Second, it reviews the main studies in the existing literature related to price differential for both classes of shares. Third, it tests several measures for liquidity, and control and ownership, besides the characteristics of dual class shares as determinants for their price differential.

This paper is organized as follows: Section 2 reviews recent changes in legislation related to corporations, including changes in the Corporate Law and CVM Instructions (Comissão de Valores Mobiliários - Brazil's equivalent to the Securities and Exchange Commission in the US) which could have influenced the price differentials. Section 3 presents a brief revision of the literature related to price differentials and their determinants, including private benefits and liquidity. The sample and the main statistics description are presented in Section 4. Section 5 presents and discusses the results of the empirical analysis. Final comments are presented in Section 6.

\section{Institutional Framework.}

It is particularly important to review the legal issue of investors' rights as an essential element of corporate governance according to Shleifer and Vishny (1997). Empirical evidence from La Porta et al. (2000) shows that the equity market value reflects the level of minority shareholders' legal protection. Different levels of protection 
Determinants of the Differential Pricing between Voting and Non-Voting Shares

for voting and non-voting shareholders can therefore reflect price differentials between classes of shares.

The period of analysis starts in July 1994 and ends in June 2002. During this period, control transfer rules for companies listed on the São Paulo Stock Exchange ("BOVESPA") may have impacted the price differential of share classes in Brazil. Notably we emphasize (a) Law 9457 as of May 5, 1997, and (b) Law 10303 as of October 31, 2001. Subsection 2.1 presents the status of the Corporate Law, and subsection 2.2 presents the main implications of Laws 9457 and 10303 on price differential between voting and non-voting shares.

\subsection{Corporate Law.}

Every listed company must be incorporated in Brazil as a corporation ("Sociedade por Ações - SA"). The basic rules of a corporation's constitution and operation are contained in Law 6404 as of December 15, 1976. Law 6404 has had several changes over time, two of them being of major interest for the present discussion: Law 9457 of May 1997, and Law 10303 of October 2001. According to the Corporate Law, shares represent the firm's capital, and the shareholders' liability is limited to the issuance price of acquired or underwritten shares. In addition, a corporation listed on the stock exchange is subject to the CVM's rules, besides the rules of the stock exchange where the stock is listed.

The capital of most Corporations can be constituted of common shares (with voting rights) and preferred shares (non-voting rights). Until October 2001, publicly held firms could have up to two-thirds of their shares as non-voting preferred shares. After Law 10303 came into force, those non-voting shares were limited to a maximum of $50 \%$ of the total shares issued by (a) new corporations established after the enactment of those new rules, or (b) existing corporations which opted to go public after the enforcement of the new law. 
Preferred non-voting shareholders - whose stocks are entitled to a minimum or fixed dividend payout - can acquire voting rights if the company fails to pay dividends for three years in a row (Law $6404 \mathrm{Ar}-$ ticle $111 \S 1^{\circ}$ ), except if the company's by-laws do not foresee a term less than three years. In addition, Law 6404 establishes that companies must distribute to all its shareholders (ONs and PNs) mandatory dividends corresponding to not less than $25 \%$ of the adjusted net income (Article $202, \S 2^{\circ}$ ), or $50 \%$ of the adjusted net income in case the by-laws are negligent (Article 202, I). This mandatory dividend is shared among shareholders according to the type of dividend for PNs (fixed, minimum, $10 \%$ higher than ONs, equal to ONs) and for ONs.

\subsection{Changes in legislation and implications for the price differentials.}

The main change in legislation regarding corporations started with the introduction of Law 9457 as of May 5, 1997. Law 9457 revoked tag along rights of minority voting shareholders. This has aided the federal government in privatizing major listed companies by avoiding sharing the capital gains from the sale of control with minority voting shareholders. This possibly implied a discount for common voting shares vis-à-vis preferred non-voting shares until the enforcement of Law 10303. This latter law establishes that voting minority shareholders are entitled to at least $80 \%$ of the price paid to the control block in the event of a transfer of control. In this subsection, I analyze the implications of the main changes in the Corporate Law and the rules of control transfer, and their impact on price differentials.

To summarize, Law 9457 as of May 5, 1997 revoked Article 254 of Law 6404, which established a mandatory offer for all voting shares in the event of a transfer of control in the same terms offered for the 
purchase of the control block. Non-voting shares have never been subject to a mandatory offer according to the Brazilian legislation. Moreover, Law 9457 eliminated withdrawal rights from shareholders in the event of a spin-off of the company. Before its enactment, dissenting shareholders had the right to withdraw at a price equal to at least the equivalent to book value. As for the withdrawal price to be paid to the dissenting shareholder, Law 9457 allowed companies to establish some criteria in their by-laws to calculate the withdrawal value, in case the proposed price was inferior to book value.

Another relevant change was the introduction of CVM Instruction 299 as of February 9, followed by CVM Instruction 345 as of September 4 2000, both later revoked and consolidated by CVM Instruction 361 as of March 5, 2002. CVM Instructions 299 and 345 introduced the price disclosure rules in the event of a transfer of control (e.g. terms, prices, etc). In the pre-1997 period, dissenting shareholders had withdrawal rights at book value, as a minimum established price. This was particularly relevant to non-voting shareholders, once they did not enjoy the possibility of tag along rights as was the case with voting minority shareholders.

Law 10303 aims at minimizing some negative impacts on both voting and non-voting shareholders that do not belong to the control block. For minority voting shareholders, Law 10303 reinstates the mandatory acquisition of shares for at least $80 \%$ of the price paid to controlling shareholders. Additionally, the law foresees additional advantages to non-voting shares as a condition for trading in the open market. Briefly, advantages include one of the following options: (a) priority to receive a minimum dividend corresponding to at least $3 \%$ of book value; (b) dividends $10 \%$ superior to those paid for common voting shares; or (c) the tag along right for $80 \%$ of the price paid to the controlling shareholder(s) in the event of a control transfer. The mandatory change in by-laws to adapt or include one of the above 
items shall be completed by March 2003. The previous item (b) was subject to the advantage offered to non-voting shareholders during the enforcement of Law 9457.

Law 10303 also sets forth the withdrawal right in the event of a merger, acquisition and spin-off if there is no liquidity and dispersion by type and class of share. Liquidity can be defined as the share of each type and class of stock in the local or international equity index. The withdrawal right remains in the case of a partial acquisition that results in a change in the nature of the company, reduction of mandatory dividend or share in corporate groups. The changes in non-voting rights will not imply withdrawal rights provided they are done before December 312002.

The delisting of a publicly held company at CVM is established through a public tender offer at a fair price. The basis for calculation goes from book value to the use of assessments based on multiples, discounted cash flow and market price. Minority shareholders - who represent a minimum of $10 \%$ of the outstanding shares - may not agree with the offer price, requiring a reassessment, and refusing the delisting by not accepting the offer.

Law 10303 has established a new writing for Law $6404 \S 6$ article 4 - which reinforces the need of a public tender offer (PTO) in case the controlling shareholder rises his or her share in a given class of share, compromising its liquidity. CVM Instruction 361 determines a PTO whenever the controlling shareholder acquires by any means other than a PTO, more than one-third of each class of outstanding shares. If the controlling shareholder acquires more than $10 \%$ of the outstanding shares (even if it is less than one-third), then CVM is entitled to require a PTO within six months. Alternatively, the controlling shareholder who exceeds the limit of one-third may offer to sell his or her excess shares within three months.

Finally, the Corporate Law in force does not establish a qualified 
or special quorum for the approval of redemption. Therefore, this redemption - unless otherwise specified in the company's by-lawswill depend on the approval of at least $50 \%$ of shareholders of the affected class (Law $10303 \S 6$ art. 44).

The hypothesis related to the effects of the main changes in legislation on price differentials between voting and non-voting stocks is as follows:

H1: The voting premium decreased during the regime of Law 9457, implying less value to voting shares vis-à-vis non-voting shares, ceteris paribus. On the other hand, the voting premium increased as a result of the inclusion of tag along rights under Law 10303 implying more value to voting shares, ceteris paribus.

\section{Determinants of Price Differentials between ON and PN.}

As the subject of this study, I analyze the possible determinants of price differentials between voting and non-voting stocks in the Brazilian market: (i) private benefits of control, (ii) preference for liquidity, and (iii) other inherent characteristics of shares (e.g. dividend differential). The following subsections discuss the contributions of each determinant, and how these determinants can influence price differentials.

\subsection{Private Benefits of Control.}

The separation of a company's ownership and control provides an incentive to managers using part of the resources for their own benefit (Berle and Means (1932)). A similar conflict occurs between controlling and minority shareholders. Jensen and Meckling (1976) argue that majority shareholders, who control the firm's resources, enjoy private benefits. 


\section{Richard Saito}

The three most used structures for separating ownership and control include: (i) stock pyramids, (ii) cross-ownership structures, and (ii) structures with more than one class of shares ("dual class structures"). Bebchuck, Kraakman and Triants (1999) discuss the main reasons for choosing each structure when separating ownership and control, and the respective agency costs. Notably, the use of dual class share is more frequent in Europe, Asia and South America. In the United States, dual class shares have become more popular since the 1980s, particularly after the New York Stock Exchange decided to exclude firms with more than one class of shares with voting differential ${ }^{3}$.

Harris and Raviv (1988) define private benefits of control as some "physical" value attributed to control. Dyck and Zingales (2002) discuss typical power abuses by the controlling shareholder. For example, the use of the company's resources to pay debts and transfer loans to affiliated companies. Another example mentioned is the "unfair" transfer price of an asset or product to another company and/or to the controlling shareholder to the detriment position of the minority shareholder. According to all previous examples, benefits are not enjoyed equally by all shareholders. On the other hand, the controlling shareholder may incur costs, such as fewer possibilities of diversification and civil responsibility for his or her acts, which could bring lawsuits against him or her, in extreme cases.

The measurement of these benefits has been subject to several studies by researchers, despite the well-known difficulty in having a direct measure. Barclay and Holderness (1989) quantify these benefits through the premium paid for the transfer of control in relation to

\footnotetext{
${ }^{3}$ For example, a firm with two classes of shares, $\underline{A}$ and $\underline{B}$, where shareholders of the $\underline{A}$ class have the right to five votes per share, and shareholders of the $\underline{B}$ class have the right to one vote per share.
} 
the value traded on stock exchange. Another way of estimating the value of private benefits of control is through price differentials between two classes of stocks (with voting and non-voting rights). This approach was used by Rydqvist (1987), Zingales (1994 and 1995), Nenova (2001), and Dyck and Zingales (2002).

Dyck and Zingales (2002) measure private benefits of control for companies listed in 39 countries based on 412 transfers of control blocks between 1990 and 2000. The authors find that the control value ranges from $-4 \%$ to $+65 \%$ with an average of $14 \%$. For Brazil, the premium of control transfer obtained by Dyck and Zingales (2002) was $+65 \%$. In parallel, for a sample of 20 transactions of voting stock transfer, Valadares (2002) obtains a premium paid with a median of $+80 \%$ for the period from January 1993 to January 1997.

As mentioned by Nicodano (1998), these private benefits will be larger the least the capital used to control a larger volume of assets. Nicodano defines private benefit multiplier (PBM) as the ratio of assets under control to the capital required to obtain corporate control. Two forms of obtaining a higher PBM are (a) leverage using non-voting shares, and (b) financial leverage.

The use of non-voting share in the company's capital enables the controlling shareholder to leverage resources with non-voting shareholders. As suggested by Harris and Raviv (1988), Grossman and Hart (1988), and empirically confirmed by Zingales (1994, 1995), the use of that shareholding leverage implies a higher PBM, and therefore, a higher voting premium. The second hypothesis is as follows:

H2: The voting premium will be higher if the share of ON shares in the company's capital is higher.

As for the financial leverage effect, Hoffman-Burchardi (1999) 
argues that at low rates of debt, a higher debt index increases the PBM. On the other hand, a higher debt increases the likelihood of bankruptcy, and thus increases the likelihood of control being transferred to creditors. Therefore, it is estimated that financial leverage would positively have an impact on the voting premium, but at decreasing rates, implying the hypothesis:

H3: Financial leverage has a non-linear effect on the voting premium. For low levels of debt, leverage has a positive impact, whereas for high levels of debt the relation is the opposite due to the increased likelihood of control transfer to creditors.

The controlling shareholder's share in non-voting shares may be relevant in determining the voting premium. As suggested by Megginson (1990), the higher the major shareholders' share in non-voting shares, the greater the insiders' incentive to protect non-voting shareholders. On the other hand, a positive impact is expected the higher the major shareholder's share in ON shares. The following hypothesis reflects this conjecture.

H4: The percentage of PN shares held by the major shareholder has a negative impact on the voting premium whereas the opposite occurs for $O N$ shares.

Zingales (1995) suggests that the size may influence the likelihood of control transfer in the US equity market, e.g., larger companies are less likely to suffer a control transfer, implying a lower voting premium. This evidence was not confirmed by Zingales (1995), but was confirmed by Smith and Amoako-Adu (1995) for the Canadian equity market where companies are relatively smaller than the US ones. I test the hypothesis:

H5: Voting premium is negatively related to the size of the company. 
Determinants of the Differential Pricing between Voting and Non-Voting Shares

\subsection{Liquidity.}

The second possible determinant of price differentials between $\mathrm{ON}$ and PN shares is the relative liquidity. Superior voting shares (e.g. ON) are likely to have fewer outstanding shares, and, therefore, less liquidity once they are acquired for control purposes. Amihud and Mendelson (1988) provide evidence that the price of assets is positively related to liquidity. The fact that superior voting shares (e.g. ON) are likely to have less liquidity than restricted ones (e.g. PN) may imply a discount due to their lack of liquidity.

There are several ways to measure liquidity. First, the bid-ask spread is an indicator of lack of liquidity implicit in the markets (see Neumann (2002)).

Second, it is possible to use a dummy variable for shares that are included in a local or in an international equity index. That was the approach used by Hoffmann-Burchardi (1999) when he analyzed the German equity market associating share liquidity with its inclusion in the German Equity Index - DAX. Hoffmann-Burchardi observed that shares included in $D A X$ have a lower discount for liquidity. However, the use of this concept foresees a stability of liquidity concept over time, since its inclusion in the index can change over time.

Third, Zingales (1995) suggests that the relative volume between the two classes of shares would represent an indicator of relative liquidity. Nevertheless, Zingales does not find any impact of this relative liquidity index to explain price differentials in the US equity market.

Finally, Bruni and Famá (1998) analyze the relationship between the share liquidity and its return in the period 1988-1996 on BOVESPA. The authors find a significant positive relationship between the share return and its liquidity - measured by the average BOVESPA trading index. 
This paper investigates how liquidity affects price differentials between ON and PN shares. Following previous studies, it analyzes the influence of three indicators of relative liquidity on price differentials: (a) listing on local equity index, (b) relative financial volume between the two classes of shares, and (c) the ratio of BOVESPA liquidity index monthly calculated for each class. The BOVESPA trading index for each class of share is calculated as follows $100 \cdot \frac{p}{P} \cdot \sqrt{\frac{n}{N} \cdot \frac{v}{V}}$, where $p=$ number of days on which the share was traded within the month; $P=$ total number of days for the respective calendar month; $n=$ number of trades for each class of share within the month; $N=$ number of trades for each class within the month; $v=$ financial volume for trades within the month; $V=$ volume in cash for transactions with all shares within the month. I use the ratio of BOVESPA trading indexes for the two classes of shares to reflect the relative liquidity for the month. The following hypothesis reflects the influence of the relative liquidity on the voting premium:

H6: The voting premium will be directly proportional to the liquidity of the voting common share, and inversely proportional to the liquidity of the non-voting preferred share.

\subsection{Other Characteristics.}

The voting premium is influenced by other intrinsic characteristics of each class of share. Particularly, two aspects found in the Brazilian equity market may be relevant: (a) dividend differential, and (b) existence of tag along rights extensive to minority non-voting shareholders.

Some companies give a privileged dividend treatment to PN shares as an "ownership right" compensating for the restriction on 
Determinants of the Differential Pricing between Voting and Non-Voting Shares

their voting rights. Since Law 9457 came into force, followed by Law 10303, non-voting shareholders have the right to an additional $10 \%$ dividends related to voting shareholders, unless otherwise specified in the by-laws. The hypothesis regarding this differential is reflected as follows:

H7: There will be a negative implication to the voting premium, ceteris paribus, if the non-voting share is expected to receive additional dividends related to its counterpart voting share.

The existence of tag along rights in the by-laws may imply a voting premium, if it is extensive to non-voting shareholders, ceteris paribus. If the company is listed on BOVESPA at "Level 2 of Corporate Governance Practices", then all common shareholders have tag along rights in the same terms offered to controlling shareholders and, at least $70 \%$ of the control transfer price to preferred non-voting shareholders in the event of a takeover. Moreover, the voting right to non-voting shares is foreseen in cases of spin-off, acquisition, and merger of the company and approval of agreements between the company and other firms of the same group.

On October 28, 2002, there were three companies listed at Level 2: Centrais Elétricas de Santa Catarina S/A - CELESC, Marcopolo S/A and Net Serviços de Comunicação S/A. The main hypothesis that could be investigated is that companies listed at level 2 of corporate governance practices present a positive impact on the voting premium. Nevertheless, this hypothesis will not be tested since there is not enough data for an empirical analysis. 


\section{Sample Selection.}

The sample consists of listed firms that have the two classes of shares - non-voting preferred shares (PN) and voting common shares (ON) - listed on BOVESPA from July 1994 to June 2002.

I considered companies that had $\mathrm{ON}$ and $\mathrm{PN}$ shares listed and traded on BOVESPA during the period of analysis. The criterion to include companies was to consider those that had trading activities on BOVESPA with an average of at least 30 transactions a month. From a total of 113 companies that presented ON and PN shares traded in the period, 53 companies complied with this criterion.

Share prices and trade volumes were obtained from Economatica database. Data were calculated on a monthly basis. The voting premium was calculated based on the days when both classes of shares - ON and PN - were traded following Neumann's procedures (2002).

Data regarding capital structure of each company and their shareholders were collected from the Economatica database and confirmed with the available data from Annual Reports (ANs) issued by companies and delivered to CVM. It is important to note, however, that ANs do not capture shareholders in a fully and consistent way: (i) transactions are not recorded unless they involve a $5 \%$ shareholding of the company's capital, (ii) the sample is based on quarterly sources, and therefore changes in ownership during the quarter may not be reflected. Despite these factors, I consider that the sample is representative of the ownership structure of the major companies listed on BOVESPA. 
Determinants of the Differential Pricing between Voting and Non-Voting Shares

The accounting data used in this study were obtained from Economatica database and include quarterly data from the 53 firms as follows: (i) total assets, (ii) total debt, (ii) assets, (iv) dividends payout by class of share, and (v) major shareholder's participation in voting and non-voting shares.

Table I presents the voting premium for the July 1994 to June 2002 period. The median for the period was equal to -9.2 percentage points. Nevertheless, note that the median was higher in 1999 ($22.1 \%$ ) exactly in the period when there were no tag along rights for voting minority shareholders (from May 1997 to October 2001).

\section{Table I}

Voting Premium from July 1994 to June 2002

\begin{tabular}{lccclc}
\hline \multicolumn{5}{c}{ Voting Premium } \\
\hline Year & Average & Median & Minimum & Maximum & Std.Deviation \\
\hline $1994^{a}$ & $7.3 \%$ & $-5.0 \%$ & $-79.7 \%$ & $280.3 \%$ & $53.5 \%$ \\
1995 & $17.3 \%$ & $-0.1 \%$ & $-76.5 \%$ & $338.4 \%$ & $66.2 \%$ \\
1996 & $17.7 \%$ & $-3.0 \%$ & $-74.6 \%$ & $381.6 \%$ & $77.1 \%$ \\
1997 & $6.7 \%$ & $-5.6 \%$ & $-53.3 \%$ & $244.1 \%$ & $52.7 \%$ \\
1998 & $-8.3 \%$ & $-16.9 \%$ & $-58.0 \%$ & $351.8 \%$ & $41.0 \%$ \\
1999 & $-16.8 \%$ & $-22.1 \%$ & $-57.2 \%$ & $208.2 \%$ & $29.9 \%$ \\
2000 & $-13.7 \%$ & $-17.4 \%$ & $-51.4 \%$ & $208.0 \%$ & $25.1 \%$ \\
2001 & $0.6 \%$ & $-4.8 \%$ & $-42.6 \%$ & $216.7 \%$ & $27.6 \%$ \\
$2002^{b}$ & $4.1 \%$ & $-6.7 \%$ & $-49.1 \%$ & $134.7 \%$ & $32.5 \%$ \\
\hline $1994-2002$ & $-1.3 \%$ & $-9.2 \%$ & $-79.7 \%$ & $381.6 \%$ & $45.9 \%$ \\
\hline
\end{tabular}

Note: (a) July 1994 to December 1994, (b) January 2002 to June 2002. 
5. Empirical Analysis.

\subsection{Specifications.}

As discussed in Sections 2 and 3, I empirically analyze how recent changes in the corporate law, the effects of liquidity, private benefits, and intrinsic characteristics of stocks may influence price differentials between $\mathrm{ON}$ and PN shares. The specifications are applied to the July 1994 to June 2002 period, and the voting premium, $V P$, is defined as $\left(P_{O N}-P_{P N}\right) / P_{P N}$, where $P_{O N}$ and $P_{P N}$ represent the prices of $\mathrm{ON}$ and $\mathrm{PN}$ shares, respectively. The voting premium values were calculated on a monthly basis for the days when both classes of shares were traded. The independent variables can be summarized as follows:

$\log \left(V O L_{O N} / V O L_{P N}\right)$ The natural $\log$ of the ratio between monthly financial volumes of ON to PN shares.

$\log \left(I N E G_{O N} / I N E G_{P N}\right)$ The natural log of the ratio between monthly BOVESPA trading indexes of $\mathrm{ON}$ to $\mathrm{PN}$ shares.

$I B_{O N}\left(I B_{P N}\right) \quad$ Dummy Variables taking the unit value if the ON share is listed on IBOVESPA or IBX Indexes. (the same applies to PN shares).

$P A R T_{O N}$

Represents the ratio of ON shares to the company's total capital, i.e., the number of $\mathrm{ON}$ shares divided by the total number of outstanding shares (ON and PN). 
Determinants of the Differential Pricing between Voting and Non-Voting Shares

$M A J 50 O N(40)$

Dummy variable equal to 1 , if the ratio of ON shares held by the major shareholder is higher than $50 \%$ (40\%).

$M A J 20 P N$

Dummy variable equal to 1 , if the ratio of PN shares held by the major shareholder is higher than $20 \%$.

$\left(D I V_{O N}-D I V_{P N}\right) / D I V_{P N}$ The ratio of dividend differential paid between $\mathrm{ON}$ and $\mathrm{PN}$ shares to dividends paid to each PN share.

$L A W 6404$

Dummy variable equal to 1 if the month of the analysis is within July 1994 and April 1997, prior to Law 9457, when article 254 of Law 6404 was in force.

LAW9457

Dummy variable equal to 1 if the month of the analysis is within May 1997 and February 2001 - period of the Regime of Law 9457, but prior to the approval of Law 10303 by the Congress.

LAW 10303

Dummy variable equal to 1 if the month of the analysis is within March 2001 and June 2002, period in which the approval of Law 10303 began.

SIZE

Represents the natural log of total assets on the consolidated balance sheet at the end of the quarter as a proxy for the company's size. 


\section{Richard Saito}

FINLEV

Represents the company's financial leverage defined as the ratio between the difference between assets and shareholders' equity to assets.

Table II presents a summary of descriptive statistics for the main variables of the analysis.

\section{Table II}

Summary of Descriptive Statistics

\begin{tabular}{lccccccc}
\hline & Unit & Mean & Median & Max & Min & Std.Deviation & \#Obs. \\
\hline Voting Premium & $\%$ & $-1.3 \%$ & $-9.2 \%$ & $381.6 \%$ & $-79.7 \%$ & $45.9 \%$ & 3,591 \\
Assets & RS'000 & $17,328,515$ & $4,847,472$ & $169,909,948$ & 212,656 & $27,775,766$ & 3,570 \\
$\begin{array}{l}\text { Shareshoder's } \\
\quad \text { Equity }\end{array}$ & R'O00 & $2,693,750$ & 242,545 & $70,621,612$ & 107 & $7,632,305$ & 3,570 \\
Fin.Leverage & $\%$ & $52,9 \%$ & $48,4 \%$ & $97,0 \%$ & $0,1 \%$ & $24,8 \%$ & 3,570 \\
$\begin{array}{l}\text { PARTON } \\
\text { Dividends }\end{array}$ & $\%$ & $49.4 \%$ & $50.0 \%$ & $91.8 \%$ & $33.3 \%$ & $13.2 \%$ & 2,469 \\
$\begin{array}{l}\text { Differential } \\
\text { VOLON/VOLPN }\end{array}$ & $\%$ & $-11.7 \%$ & $0.0 \%$ & $364.2 \%$ & $-100.0 \%$ & $28.5 \%$ & 2,734 \\
$I N E G_{O N} / I N E G_{P N}$ & 4,082 & 0 & $9,755,209$ & 0 & 182,118 & 3,591 \\
\hline
\end{tabular}

Hypotheses $H 1$ and $H 7$ will be empirically tested, and results can be found in Section 5.2. It is worth reviewing the expected signs of ratios in other countries, and comparing them with the results expected for the Brazilian case. TABLE III presents a summary of expected signs for each variable, reflecting the hypotheses presented in Sections 2 and 3. 
Determinants of the Differential Pricing between Voting and Non-Voting Shares

\section{Table III - Hypotheses and Expected Signs}

Hypotheses will be empirically tested through regression models for the period between July 1994 and June 2002. Independent variables - described in the HYPOTHESIS column - have their expected signs according to the second column. Brief comments are on the third column.

\begin{tabular}{|c|c|c|}
\hline Hypotheses & $\begin{array}{l}\text { Expected } \\
\text { Signs }\end{array}$ & Comments \\
\hline \multicolumn{3}{|l|}{ H1: Impact of Corporate Law } \\
\hline - $L A W 6404$ & + & When Law 6404, Article 254, was \\
\hline - $L A W 9457$ & - & revoked, it is expected that the ON \\
\hline \multirow[t]{2}{*}{ - $L A W 10303$} & + & price might have been negatively \\
\hline & & affected in relation to the $\mathrm{PN}$ price. \\
\hline \multicolumn{2}{|l|}{ H2: Share of ON } & Higher share of ON implies higher \\
\hline \multirow{2}{*}{ - PARTON } & + & possibility of private benefits, and \\
\hline & & therefore, higher voting premium. \\
\hline \multirow{7}{*}{$\begin{array}{l}\text { H3: Financial Leverage } \\
\text { - } F I N L E V \\
\text { - }(F I N L E V)^{2}\end{array}$} & & At low levels of financial leverage, \\
\hline & + & a positive impact on the voting \\
\hline & - & premium is expected. Nevertheless, \\
\hline & & at high financial leverage levels, \\
\hline & & control can be transferred to \\
\hline & & creditors, implying a lower voting \\
\hline & & premium. \\
\hline \multirow{3}{*}{$\begin{array}{l}\text { H4: Major Shareholder's Share } \\
\text { - } M A J 20 P N \\
\text { - } M A J 50 O N(40) \\
\end{array}$} & & If the major shareholder has PN \\
\hline & - & shares, he may enjoy some benefits \\
\hline & + & as non-voting shareholders. \\
\hline \multirow{2}{*}{$\begin{array}{l}\text { H5: Influence of Size } \\
\text { - } S I Z E\end{array}$} & & The larger the company, the lower \\
\hline & - & $\begin{array}{l}\text { the likelihood of a control transfer. } \\
\text { (Zingales, 1995). }\end{array}$ \\
\hline \multirow{4}{*}{$\begin{array}{l}\text { H6: Liquidity Differential } \\
\text { - } L_{O g}\left(V O L_{O N} / V O L_{P N}\right. \\
\text { - IBOVON }\left(I B O V_{P N}\right.\end{array}$} & & The discount for the lack of liquidity \\
\hline & + & is analyzed for ON shares (which \\
\hline & $+(-)$ & typically have less liquidity than \\
\hline & & PN shares). \\
\hline \multirow{2}{*}{$\begin{array}{l}\text { H7: Dividend Differential } \\
\text { - }\left(D I V_{O N}-D I V_{P N}\right) / D I V_{P N}\end{array}$} & & Dividend differential directly \\
\hline & + & influences the voting premium. \\
\hline
\end{tabular}




\subsection{Results.}

Results are presented in three blocks. First, I analyze the impacts of liquidity, dividend differential, and size on the voting premium (results are shown in TABLE IV). Next, the impacts of private benefits on the voting premium are evaluated. Variables that capture these benefits include the leverage on non-voting shareholders, the financial leverage, and the major shareholders' participation in voting and non-voting shares. Results can be found in TABLE V. Finally, the issue of changes in the Corporate Law is investigated, and the results are reported in TABLE VI.

Table IV presents the regression results of the panel data, which assess the impact of liquidity, of dividend differential, and of the size of the company on the voting premium in the period between July 1994 and June 2002.

Models (1) to (3) test the hypothesis that the voting premium is influenced by the relative liquidity assessed by three measures of liquidity: relative financial volume, ratio of liquidity indexes, and listing on local equity indexes. Results show that the relative financial volume - $\log \left(V O L_{O N} / V O L_{P N}\right)$ - and the ratio of trading indexes - $\log \left(I N E G_{O N} / I N E G_{P N}\right)$ - impact positively on the voting premium and are significant at a level of $1 \%$. The signs for listing on local equity indexes - $I B_{O N}\left(I B_{P N}\right)$ - support that the relative liquidity influences and explains part of the discount on the voting premium at a level of $5 \%$. 


\section{Table IV - Impact of Liquidity, Dividend Differential and Size of the Company on the Voting Premium}

The voting premium determinants, $V P$, are analyzed using a simple panel data model with random effects. $V P$ - the dependent variable - is the voting premium, calculated as the ratio of the difference of $O N$ and $P N$ prices to the PN price. $\log \left(V O L_{O N} / V O L_{P N}\right)$ captures the relative liquidity defined by the natural $\log$ of the ratio of financial volumes traded of ON to PN shares. $\log \left(I N E G_{O N} / I N E G_{P N}\right)$ measures the relative liquidity represented by the ratio of the trading indexes of $O N$ to $\mathrm{PN}$ shares. $I B O N$ is a dummy variable equal to 1 if the respective ON share is listed on IBOVESPA or IBX Index, the same is applied to non-voting shares through dummy IBPN. ( $\left.D I V_{O N}-D I V_{P N}\right) / D I V_{P N}$ represents the relative differential paid for each ON and PN share relative to dividends paid to each PN share.SIZE is the natural log of the company's consolidated assets. Statistics $t$ in italics can be found below the ratio, and are corrected for heteroskedasticity and autocorrelation. (a), (b) and ${ }^{(c)}$ indicate a level of significance of $1 \%, 5 \%$ and $10 \%$, respectively.

\begin{tabular}{|c|c|c|c|c|c|c|}
\hline \multirow[t]{2}{*}{ Regression Models (1)-(6) } & \multicolumn{5}{|c|}{ Dependent Variable: Voting Premium $(V P)$} & \multirow[b]{2}{*}{$(6)$} \\
\hline & $(1)$ & $(2)$ & $(3)$ & $(4)$ & $(5)$ & \\
\hline \multirow[t]{2}{*}{ Intercept } & 0.063 & 0.047 & 0.012 & $0.147^{b}$ & $0.842^{a}$ & $1.107^{a}$ \\
\hline & 1.16 & 0.91 & 0.23 & 2.31 & 4.35 & 4.80 \\
\hline \multirow[t]{2}{*}{$\log \left(V O L_{O N} / V O L_{P N}\right)$} & $0.035^{a}$ & & & $0.052^{a}$ & $0.033^{a}$ & $0.050^{a}$ \\
\hline & 9.08 & & & 11.20 & 8.62 & 10.60 \\
\hline \multirow[t]{2}{*}{$\log \left(I N E G_{O N} / I N E G_{P N}\right.$} & & $0.027^{a}$ & & & & \\
\hline & & 7.36 & & & & \\
\hline \multirow[t]{2}{*}{$I B O N$} & & & $0.050^{b}$ & & & \\
\hline & & & 2.32 & & & \\
\hline \multirow[t]{2}{*}{$I B_{P N}$} & & & $-0.066^{b}$ & & & \\
\hline & & & $(3.15)$ & & & \\
\hline \multirow[t]{2}{*}{$\left(D I V_{O N} / D I V_{P N}\right) D I V_{P N}$} & & & & $0.122^{a}$ & & $0.116^{a}$ \\
\hline & & & & 4.50 & & 4.31 \\
\hline \multirow[t]{2}{*}{$S I Z E$} & & & & & $-0.050^{a}$ & $-0.061^{a}$ \\
\hline & & & & & $(4.18)$ & $(4.33)$ \\
\hline \# Data & 3,520 & 3,591 & 3,591 & 2,679 & 3,505 & 2,672 \\
\hline$R^{2}-A j u s t e d$ & $54.6 \%$ & $51.3 \%$ & $50.7 \%$ & $57.3 \%$ & $54.7 \%$ & $57.6 \%$ \\
\hline
\end{tabular}


Moreover, differences between models (1)-(3) illustrate the sensitivity of specifications to the same concept - where liquidity is significant - and support HYPOTHESIS H1. Results point out that the relative financial volume has a greater explanatory power - measured by $R^{2}$-adjusted equal to $54.6 \%$ - than the ratio of the trading index of ON to PN (with $R^{2}$-adjusted equal to $51.3 \%$ ), although both coefficients are significant at $1 \%$. Therefore, I use the relative financial volume - $\log \left(V O L_{O N} / V O L_{P N}\right)$ - as a proxy of liquidity for the following models.

Model (4) investigates the influence of dividend differential $\left(D I V_{O N}-D I V_{P N}\right) / D I V_{P N}$ - on the voting premium. As expected, the ratio is positive and statistically significant at $1 \%$, supporting HYPOTHESIS H7. $R^{2}$-adjusted (equal to $57.3 \%$ ) is higher than the one found in model (1), providing greater explanatory power to the model.

Finally, models (5) and (6) introduce the size of the company represented by the natural log of their assets. For both specifications the ratio is negative and statistically significant at $1 \%$ supporting HYPOTHESIS H5, i.e., the larger the company, the lower the voting premium. The inclusion of the variable SIZE did not imply a higher $R^{2}$-adjusted, though.

Models (7)-(11) analyze the impact of ownership and capital structures on the voting premium. Higher leverage using non-voting shares and debt are analyzed in models (7) and (8). Models (9) to (11) investigate the ownership structure, and the major shareholder's participation in ON and PN shares, and its impact on the voting premium. Results can be found in Table V.

Results of models (7) and (8) support HYPOTHESES H2 and 
H3, respectively. Note that the coefficient for PARTON is positive and statistically significant at $1 \%$, confirming the assumption that a higher leverage on non-voting shareholders is positively related to the voting premium. In addition, coefficients for FINLEV and $(F I N L E V)^{2}$ are positive and negative, respectively, supporting the hypothesis that at low levels of debt the MPB multiplier is beneficial to voting shareholders. Nevertheless, at high levels of debt, gains from this multiplier should be balanced probably with bankruptcy risks, implying a negative relation to the voting premium.

Results of models (9) to (11) do not support HYPOTHESIS H4. The coefficient for MAJPN20 is positive and statistically significant at a level of $10 \%$, the coefficient for MAJON40 is negatively significant at $5 \%$. Nevertheless, the result in model (11) contradicts HYPOTHESIS $\mathbf{H 4}$ regarding the major shareholder's participation in PN shares, once the coefficient for MAJ20PN is positive and statistically significant at $1 \%$. A possible explanation is that the higher the major shareholder's participation in non-voting shares, the lower the liquidity for non-voting stocks, implying a positive impact on the voting premium.

Finally, I tested the impacts of the recent changes in Corporate Law on the voting premium. I use dummy variables to capture the period of enforcement of the three subperiods - LAW6404, $L A W 9457$, and $L A W 10303$ - as discussed in Section 2. Model (12) in TABLE VI confirms that the coefficient for $L A W 6404$ is positive and statistically significant at $1 \%$, whereas model (13) confirms that during the enforcement of $L A W 9457$ - period in which there wcre no tag along rights to voting minority shareholders - is negatively related to the voting premium. This coefficient is negative and statistically 
significant at $1 \%$. And finally, I use two additional models to analyze the reinstatement of tag along rights to voting minority shareholders under Law 10303. Results in models (14) and (15) confirm that the introduction is positively related and statistically significant at $1 \%$.

These latter results are consistent with Neumann (2002) and Hoffman-Burchardi (1999). Studies conducted in the Danish and German markets, respectively, confirm that in the absence of tag along rights, there is a negative impact on the voting premium, and after the reintroduction of the tag along rights, the impact on the price differential is positive.

\section{Table V - Private Benefits and Voting Premium}

The voting premium determinants, $V P$, are analyzed using a simple panel data model with random effects. $V P$ - the dependent variable - is the voting premium, calculated as the ratio of the difference between $\mathrm{ON}$ and PN prices to the PN price. $\log \left(V O L_{O N} / V O L_{P N}\right)$ captures the relative liquidity defined by the natural log of the ratio of financial volumes traded of ON to PN. (DIVON-DIVPN)/DIVPN represents the relative dividend differential paid for each $O N$ and $P N$ share relative to dividends paid to each PN share. $S I Z E$ is the natural log of the company's consolidated assets. PARTON represents the ratio of voting shares to the total shares at the end of each year. FINLEV is a proxy for financial leverage, MAJ50ON (MAJ40ON) is a dummy with value equal to one, if the major shareholder holds more than $50 \%$ (or $40 \%$ ) of the voting shares. $M A J 20 P N$ is a dummy with value equal to one, if the major shareholder holds more than $20 \%$ of the non-voting shares. Statistics $t$ in italics can be found below the ratio, and are corrected for heteroskedasticity and autocorrelation. ${ }^{(a)},{ }^{(b)}$ and ${ }^{(c)}$ indicate a level of significance of $1 \%, 5 \%$ and $10 \%$, respectively. 
Determinants of the Differential Pricing between Voting and Non-Voting Shares

\begin{tabular}{|c|c|c|c|c|c|}
\hline \multirow[t]{2}{*}{ Regression Models (7)-(11) } & \multicolumn{5}{|c|}{ Dependent Variable: Voting Premium $(V P)$} \\
\hline & $(7)$ & (8) & (9) & $(10)$ & $(11)$ \\
\hline \multirow[t]{2}{*}{ Intercept } & $2.310^{a}$ & $3.982^{a}$ & $4.118^{a}$ & $3.845^{a}$ & $4.312^{a}$ \\
\hline & 6.66 & 8.47 & 8.67 & 8.13 & 9.08 \\
\hline \multirow[t]{2}{*}{$\log \left(V O L_{O N} / V O L_{P N}\right)$} & $0.065^{a}$ & $0.059^{a}$ & $0.060^{\circ}$ & $0.058^{a}$ & $0.059^{a}$ \\
\hline & 11.87 & 10.66 & 10.77 & 10.51 & 10.65 \\
\hline \multirow[t]{2}{*}{$\left(D I V_{O N} / D I V_{P N}\right) / D I V_{P N}$} & $0.061^{b}$ & $0.056^{c}$ & 0.064 & 0.049 & $0.066^{b}$ \\
\hline & 2.00 & 1.85 & 2.10 & 1.59 & 2.15 \\
\hline \multirow[t]{2}{*}{$S I Z E$} & $-0.176^{a}$ & $-0.251^{a}$ & $-0.257^{a}$ & $-0.248^{a}$ & $-0.274^{a}$ \\
\hline & $(9.23)$ & $(9.27)$ & $(9.43)$ & $(9.13)$ & $(10.02)$ \\
\hline \multirow[t]{2}{*}{$P A R T_{O N}$} & $1.389^{a}$ & $1.351^{a}$ & $1.231^{a}$ & $1.493^{a}$ & $1.192^{a}$ \\
\hline & 6.57 & 6.43 & 5.61 & 6.80 & 5.46 \\
\hline \multirow[t]{2}{*}{$F I N L E V$} & & $2.192^{a}$ & $2.234^{a}$ & $2.084^{a}$ & $2.103^{a}$ \\
\hline & & 4.90 & 4.99 & 4.64 & 4.72 \\
\hline \multirow[t]{2}{*}{$(F I N L E V)^{2}$} & & $-2.277^{a}$ & $-2.318^{a}$ & $-2.142^{a}$ & $-2.126^{a}$ \\
\hline & & $(4.21)$ & $(4.28)$ & $(3.94)$ & (3.94) \\
\hline \multirow[t]{2}{*}{$M A J 50 O N$} & & & $0.042^{c}$ & & -0.004 \\
\hline & & & 1.91 & & $(0.18)$ \\
\hline \multirow[t]{2}{*}{$M A J 40 O N$} & & & & $-0.55^{b}$ & \\
\hline & & & & $(2.22)$ & \\
\hline \multirow[t]{2}{*}{$M A J 20 P N$} & & & & & $0.127^{a}$ \\
\hline & & & & & 4.65 \\
\hline \# Data & 1,762 & 1,762 & 1,762 & 1,762 & 1,762 \\
\hline$R^{2}-$ Adjusted & $65.2 \%$ & $65.7 \%$ & $65.8 \%$ & $65.8 \%$ & $66.2 \%$ \\
\hline
\end{tabular}




\section{Richard Saito}

\section{Table VI - Recent Changes in Corporate Law and Voting Premium}

The voting premium determinants, $V P$, are analyzed using a simple panel data model with random effects. $V P$ - the dependent variable - is the voting premium, calculated as the ratio of the difference of $O N$ and $P N$ prices to the PN price. $\log \left(V O L_{O N} / V O L_{P N}\right)$ captures the relative liquidity defined by the natural log of the ratio of financial volumes traded of $O N$ to $P N$ shares. $\left(D I V_{O N}-D I V_{P N}\right) / D I V_{P N}$ represents the relative dividend differential paid for each $O N$ and $P N$ share relative to dividends paid to each PN share. $S I Z E$ is the natural log of the company's consolidated assets. PARTON represents the ratio of common shares to the total stock at the beginning of each year. $L A W 6404, L A W 9457, L A W 10303$ are dummies equal to one, if the respective Law is in force in the period between July 1994 and September 2002. Statistics $t$ in italics can be found below the ratio, and are corrected for heteroskedasticity and autocorrelation. ${ }^{(a)},(b)$ and ${ }^{(c)}$ indicate a level of significance of $1 \%, 5 \%$, and $10 \%$, respectively.

\begin{tabular}{|c|c|c|c|c|}
\hline \multirow[t]{2}{*}{ Regression Models (12)-(15) } & \multicolumn{4}{|c|}{ Dependent Variable: Voting Premium $(V P)$} \\
\hline & $(12)$ & (13) & (14) & (15) \\
\hline \multirow[t]{2}{*}{ Intercept } & $1.353^{a}$ & $2.042^{a}$ & $2.996^{a}$ & $2.019^{a}$ \\
\hline & 3.42 & 5.91 & 8.08 & 4.89 \\
\hline \multirow[t]{2}{*}{$\log \left(V O L_{O N} / V O L_{P N}\right)$} & $0.064^{a}$ & $0.062^{a}$ & $0.064^{a}$ & $0.062^{a}$ \\
\hline & 11.67 & 11.47 & 11.69 & 11.47 \\
\hline \multirow[t]{2}{*}{$\left(D I V_{O N} / D I V_{P N}\right) / D I V_{P N}$} & $0.023^{b}$ & 0.008 & $0.051^{c}$ & 0.010 \\
\hline & 0.74 & 0.26 & 1.67 & 0.31 \\
\hline \multirow[t]{2}{*}{$S I Z E$} & $-0.117^{a}$ & $-0.154^{a}$ & $-0.221^{a}$ & $-0.161^{a}$ \\
\hline & $(5.21)$ & $(8.12)$ & $(10.57)$ & $(6.79)$ \\
\hline \multirow{2}{*}{ PARTON } & $1.345^{a}$ & $1.346^{a}$ & $1.394^{a}$ & $1.349^{a}$ \\
\hline & 6.39 & 6.44 & 6.62 & 6.45 \\
\hline \multirow[t]{2}{*}{$L A W 6404$} & $0.112^{a}$ & & & $0.119^{a}$ \\
\hline & 4.94 & & & 5.29 \\
\hline \multirow[t]{2}{*}{$L A W 9457$} & & $-0.125^{a}$ & & \\
\hline & & $(7.35)$ & & \\
\hline \multirow[t]{2}{*}{$L A W 10303$} & & & $0.125^{a}$ & $0.133^{a}$ \\
\hline & & & 5.08 & 5.44 \\
\hline \# Data & 1,762 & 1,762 & 1,762 & 1,762 \\
\hline$R^{2}-$ Adjusted & $65.6 \%$ & $66.2 \%$ & $65.8 \%$ & $66.2 \%$ \\
\hline
\end{tabular}


Determinants of the Differential Pricing between Voting and Non-Voting Shares

\section{Final Comments.}

Several papers suggest that private benefits can explain price differentials between classes of stocks with different voting rights. However, in Brazil the price differential between voting and nonvoting stocks is negative for several companies in the period between July 1994 and September 2002. The present paper investigated the determinants that allow this discount on the voting share vis-à-vis the non-voting share.

The empirical analysis supported the hypothesis that liquidity is relevant to the determination of relative prices. In addition, empirical evidence confirms the negative impact of Law 9457, and the positive impact of the introduction of Law 10303, reinstating tag along rights to voting minority shareholders. Moreover, the ownership structure showed a positive relation to the voting premium, but the major shareholder's share in voting stocks did not present a significant relationship.

Finally, it is worth mentioning that companies must include one of the following options in their by-laws by March 2003: (a) priority over receiving a minimum dividend corresponding to at least $3 \%$ of book value; (b) dividends $10 \%$ higher than those paid to voting shares; or (c) tag along rights at $80 \%$ of the price paid to the controlling shareholder(s) in the event of a control transfer. A possible future investigation would be to analyze the impact on companies by choosing one of the above three options for the voting premium.

Submitted in February 2001. Revised in February 2003. 
Richard Saito

\section{References}

Amihud, Y. \& H. Mendelson 1988. "Liquidity and Asset Prices: Financial Management Implications", Financial Management, 17:5-15.

Barclay, M. J. \& Holderness, C. G. 1989. "Private Benefits from Control of Public Corporations", Journal of Financial Economics, 25:371-395.

Bebchuk, L., Kraakman, R., \& Triants, G. 1999. "Stock pyramids, cross-ownership, and dual class equity: The creation and agency costs of separating control from cash flow rights", National Bureau of Economic Research, NBER Working Paper Series \# 6951, New York.

Berle, A. A. \& G. C. Means 1932. The Modern Corporation and Private Property, Macmillan, New York.

Bruni, A. L. \& Famá, R. 1998. Liquidez e Avaliação de Ativos Financeiros: Evidências Empíricas na Bovespa, In: ANPAD, Anais do ENANPAD, Foz do Iguaçu, 1998.

Dyck, A. \& Zingales, L. 2002. "Private Benefits of Control: An International Comparison", National Bureau of Economic Research, NBER Working Paper Series 8711, New York.

Grossman, S. \& Hart, O. 1988. "One Share-One Vote and the Market for Corporate Control", Journal of Financial Economics 20:175-202.

Harris, M. \& Raviv, A. 1988. "Corporate Control Contests and Capital Structure", Journal of Financial Economics 20:203-235.

Hoffman-Burchardi, U. 1999. "Corporate Governance Rules and the Value of Control - A Study of German Dual Class Shares". Financial Markets Group, Discussion Paper \#315, London School of Economics. 
Determinants of the Differential Pricing between Voting and Non-Voting Shares

Horner M. 1998. "The Value of the Corporate Voting Right", Journal of Banking and Finance, 12:69-83.

Jensen, M. C. \& Meckling, W. H. 1976. "Theory of the Firm: Managerial Behavior, Agency Costs and Ownership Structure", Journal of Financial Economics, 11:5-50.

La Porta, R., Lopez-de-Salines, F., \& Shleifer, A. 2000. "Investor Protection and Corporate Governance", Journal of Financial Economics, 59(1-2):3-27.

Lease, R. C.; J. J. McConnell \& W. H. Mikkelson 1983. "The Market Value of Control in Publicly Traded Corporations". Journal of Financial Economics, 11: 439-471.

Levy, H. 1983. "Economic Evaluation of Voting Power of Common Stock". Journal of Finance, 38:79-93.

Nicodano, G. 1988. "Corporate Groups, Dual Class Shares and the Value of Voting Rights", Journal of Banking and Finance, 22(9):1117-1137.

Megginson, W. L. 1990. "Restricted Voting Stock Acquisition Premiums and the Market Value of Corporate Control". Financial Review, 25:175-198.

Nenova, T. 2001. "The value of corporate votes and control benefits: A cross-country analysis", mimeo., Harvard University, Department of Economics.

Neumann, R. 2002. "Price Differentials between Dual-Class Stocks: Voting Premium or Liquidity Discount?" In: European Financial Management Association, 2003 Annual Meetings, Helsinki, Conference Proceedings, to appear.

Smith, B. F. \& Amoako-Adu, B. 1995. "Relative Prices of Dual Class Shares", Journal of Financial and Quantitative Analysis, 30(2):223-239. 
Ødergaart, B. A. 1988. "Price differences between equity classes. Corporate Control, Foreign Ownership or Liquidity? Evidence from Norway", mimeograph, Norwegian School of Business.

Rydqvist, K. 1987. "Empirical investigation of the voting premium". Working paper \#35, Northwestern University.

Shleifer, A. \& Vishny, W. 1987. "A Survey of Corporate Governance", Journal of Finance, 52:737-783.

Valadares, S. 2002. Estimativa de valor de controle no Brasil, In: M. Bonomo (org.) Finanças Aplicadas no Brasil, FGV Editora, Rio de Janeiro, Chapter 11, p. 299-312

Zingales, L. 1994. "The value of the voting right: a study of the Milan Stock Exchange experience", Review of Financial Studies, 62:125-148.

Zingales, L. 1995. "What determines the value of corporate votes?" Quarterly Journal of Economics, 110:1047-73. 
